\title{
Histological studies of the pheromone-producing gland in female of Spodoptera littoralis (Lepidoptera: Noctuidae)
}

\author{
Nasra M. H. Zohry \\ Department of Zoology, Faculty of Science, Sohag University, Egypt
}

\begin{abstract}
Sex pheromone gland in female Spodoptera littoralis was studied histologically. The scent gland is located in the body cavity beneath the $7^{\text {th }}$ and $8^{\text {th }}$ abdominal tergites and ventrally around the ninth segments. The gland lies in the body cavity has an eversible sac forming a ring shaped structure. The eversible sac lined with cuticular layer that has spines pointing toward the lumen of the sac. The gland composed of two distinct regions secretory and storing. Cells of each region are composed of a single layer of flattened, columnar or cuboidal epithelial cells containing large circular or oval basal located nuclei and a layer of cuticle covering the epithelial cells with distinct spines. PAS-positive substances were demonstrated intracellular for both regions. In addition, the leuminal contents within the storing region are intensely PAS stained. Transmission electron microscopy of the ventral surface of the $9^{\text {th }}$ segment showed the presence of electron opaque spherical bodies in the epithelial cells.
\end{abstract}

Keywords: Female sex pheromone gland, Lepidoptera, Spodoptera littoralis, Morphology, Histology.

\section{INTRODUCTION}

The sexual communication between sexes in Lepidoptera species is mediated mainly by sex pheromone, which are volatile compounds used by Lepidoptera insects to attract potential mates a distance. Sex pheromones play an important role in the elicitation of mating behavior in moths and are therefore crucial for successful mating and maintenance of reproduction. The sex pheromone-producing gland is typically situated near the abdominal tip in the intersegmental membrane between $8^{\text {th }}$ and $9^{\text {th }}$ segments (Suwanjarat\& Witethom, 1995). The morphology and histology of the female sex pheromone glands of Lepidoptera have been studied (Kou et al., 1991; Yin et al., 1991; Raspotnig et al., 2002). The sex pheromone gland of calling female Sapodilla fruit borer (SFB) has been studied histologically (Suwanjarat\& Witethom, 1995). Ma and Roelofs (2002) studied the sex pheromone gland of the female European corn borer moth, Ostrinia nubilalis using light and electron microscopy.

Also, Raina et al. (2000) studied the morphological location of the sex pheromone producing area in the ovipositor of female corn earworm Helicoverpa zea in correlation with gas chromatographic analysis of the extracted pheromone. Morphological and histological studies in the production of sex pheromone of Copitarsia consueta was carried out (Rojas et al., 1995). Steinbrect (1982) studied the location of female pheromone gland in the African armyworm moth, Spodoptera exempta. Percy-Cunningham and Macdonald (1987) identified the pheromone glands of female moths representing 16 families and studied their structural characteristics. The majority of the species examined belong to the family Noctuidae (Raina et al., 2000). In the present study the location of the sex pheromone gland of the female of S.littoralis was studied at both histological, histochemical and ultrastrctural levels. 


\section{MATERIALS AND METHODS}

\section{Insect rearing:}

Spodoptera littoralis (Boisd) larvae obtained from the laboratory culture of plant protection, Research Institute, Agricultural Research Center, Cairo, Egypt. The insects were obtained from a colony reared in the laboratory under constant laboratory conditions of $27 \pm 2^{\circ} \mathrm{C}$ and $70 \pm 5 \%$ R.H. Male and female pupae were placed in separate glass jars for adult emergence. Female moths were isolated in small glass jars to avoid copulation. Adults were provided $10 \%$ sucrose solution for feeding.

\section{Histology:}

The terminal portions of the abdomen of virgin females of one day old were extruded to normal degree by gentle squeezing and the abdomen ligated to keep the last segments extruded. The abdominal tips were cut off anterior to the ligation and the glands that found in the abdominal cavity were anesthetized. Both the abdominal tips and the glands fixed in carnoy's fluid, for half an hour, then two changes (for about 15 minute) in absolute ethyl alcohol (100\%) for dehydration. The dehydrated organs were cleared in methyl benzoate for $24 \mathrm{hrs}$, washed in toluene for three timesfive minutes each, then transferred to molten paraffin (melting point $58^{\circ} \mathrm{C}$ ) for two changes of three hrs each. Specimens were sectioned both longitudinal and transverse. Sections were stained with haematoxylin and eosin and PAS technique (Drury and Wallington, 1976). The stained sections were examined under light microscope.

\section{Transmission electron microscopy:}

For ultrastructural study the abdominal tips were fixed in $1 \%$ glutraldehyde in $0.1 \mathrm{M}$ sodium cacodylate buffer solution at $4^{\circ} \mathrm{C}$ and $\mathrm{pH} 7.2$ for 24 hours, washed in $0.1 \mathrm{M}$ sodium cacodylate buffer, post fixed in osmium tetraoxide in $0.2 \mathrm{M}$ sodium cacodylate buffer for 1 hour. The specimens were dehydrated in $70 \%, 90 \%$, and $100 \%$ ethanol and then embedded in labeled capsules with fleshy prepared resin and left to polymerize at $60^{\circ} \mathrm{C}$ for 48 hours. Several resin semithin sections were cut at approximately $1 \mathrm{um}$ thick using ultramicrotome, then stained with $1 \%$ toluidine blue in $1 \%$ borax solution for 1 minute at $80^{\circ} \mathrm{C}$. The stain was rinsed off with distilled water and the sections were dried and examined microscopically. Selected area from the trimmed blocks were cut by using a diamond knife, with the ultramicrotome set to cut at around 50-70 $\mathrm{nm}$ using heat advances. The sections were picked up onto 300 mesh copper grids stained with previously prepared methanolic uranyl acetate and examined by TEM JOEL 1010. Some of the examined fields were photographed.

\section{RESULTS}

According to the light microscopical examination of abdominal tips, the sex pheromone gland is located in the gland lies in the body cavity situated beneath the seventh and eighth abdominal tergites, the gland encircles ventrally as an invagination of the ventral intersegmental membrane between eighth and ninth segments (plate 1A). Extensive convolutions of the ventral surface were evident in the cross sections of the $9^{\text {th }}$ segments (plate1B). The gland has an eversible sac forming a ring shaped structure (plate 2A). The eversible sac lined with cuticular layer with distinct spines pointing toward the lumen of the sac (plate $2 \mathrm{~B} \& \mathrm{C}$ ). The sac is everted out for releasing the secretion (plate $3 A \& B$ ). The cuticle in the gland and its sac is thick and appeared to be divided into two distinct zones, an inner thick hyaline soft zone endocuticle and an outer zone of epicuticle (plate 4B). Beneath the cuticle is a layer of specialized epithelial cells. Two different portions are recognized in the gland, the 
anterior portion is secretory and posterior is storage (plate 4A\&B). Pheromone gland cells consisted of a single layer of two types of cells; one type is flattened with compressed nuclei found in the folds of the secretory region (plate 5A). Cells of the second type, which were present in both storage and secretory portion, are columnar cells with large circular or oval nuclei which may centric or basal in position (plate 5B). The secretory portion surrounding by muscles but the storage portion lack of muscles. PAS-positive substances were demonstrated intracellular of both regions (plate 6A, B, C\&D). In addition, the leuminal contents within the storing region are intensely PAS stained, positive pink color suggesting that the gland secretes carbohydrates (plate 6C). The apical cellular membrane differentiates into brush borders which facilitate the secretion process (plate 6D). The epithelial cells in the ventral surface of the ninth segment are flattened, contained large nuclei and the cuticle lined with cuticular spines (plate 7A,B\&C). Transmission electron microscopy of the ventral surface of the $9^{\text {th }}$ segment showing the presence of electron opaque spherical bodies in the epithelial cells (plate 7C).

\section{DISCUSSION}

The present histological examinations of the terminal abdominal segments of female of $S$. littoralis indicated that the bulk of the pheromone producing area occupied the gland lies in the abdominal cavity and ventrally in the integument around ninth segment. Suwanjarat and Witethom (1995) recorded that the sex pheromone gland is located on dorsal and ventral intersegmental membrane between the eighth and ninth segments and the gland encircles ventrally as ventrolateral sac forming a ring shaped structure. Ma and Roelofs (2002) recorded that the pheromone gland for Ostrinia nubilalis is formed by hypertrophid epidermal cells at the mid-dorsal region of the intersegmental membrane between abdominal segment 8 and 9/10. However, Raspotnig (2003) reported that the pheromone gland of Cameraria ohridella consists of a single layer of modified epidermal cell in the dorsal part of the intersegmental membrane between the eighth and ninth segments and laterally extends to the posterior apophyses. Yin et al. (1991) described the pheromone gland of Holomelina lamae as a paired tubular gland situated beneath the seventh and eighth abdominal tergites; each gland has finger like branches in the anterior portion, but is fused posteriorly to form a single duct opening in the intersegmental membrane between segments $8^{\text {th }}$ and $9^{\text {th }}$ anterior to anal papilla. The epidermal cells of pheromone gland of female $S$. littoralis exhibit typical characteristics of glandular epithelium such as apical cellular membrane foldings along the whole line between cells and the cuticle. Ma and Roelofs (2002) reported that the sex pheromone gland of the female European corn borer moth, Ostrinia nubilalis is formed by hypertrophid epidermal cells at the mid dorsal region of the intersegmental membrane between abdominal segments 8 and $9 / 10$ and the active glandular cells contain extensive apical membrane foldings. The epidermal cells of the scent glands of most Lepidoptera are columnar epithelial cells (Suwanjarat and Witethom, 1995). In Heliothis zea and Heliothis virescens (Noctuidae) the cuboidal epithelial cells are also found in the sex pheromone producing cells (Aubrey et al., 1983). The glandular cells of Spodoptera littoralis are flattened, columnar or cuboidal and contain compressed, circular or oval basal nuclei or may be centric in position. These results agree with that reported by Suwanjarat and Witethom (1995). In addition, the position of the nucleus is varied from species to species. In Choristoneura fumifera, Precy and Weatherston (1971) reported that the large ovoid nucleus of glandular cell of pheromone is in the central area of the cell. 
The cuticle covering the glandular epithelium in Spodoptera littoralis is clearly modified; it appears to be divided into two distinct zones, an inner thick hyaline soft zone endocuticle and a darker outer zone of epiculicle. Raspotnig et al. (2003) reported that the cuticle covering the glandular epithelium in C. ohridella is clearly modified; it appears to be soft, hyaline and weakly sclerotized, possibly facilitating pheromone penetration by these special qualities. At their apical side, the glandular cells directly attach to the endocuticle, which also may represent a site for pheromone accumulation. Also, Raspotnig et al. (2003) reported that the cuticle might play an important role in the regulation of pheromone emission possibly being responsible for controlled pheromone release rate in small portions. Histologically the apical plasma membrane in the cells of S.littoralis differentiates into numerous brush borders which play an important role in the secretion process. Yin et al. (1991) reported that the microvilli at the apical zone in Holomelina lamae are long and numerous, some may also possess tubules in their lumen. Similar observations were reported in Trichoplusia ni and may also facilitate transport of pheromone (Miller et al., 1967). Also, the authors recorded that pheromone may be accumulated in the microtrichia (spines) or transported the cuticular surface through the endocuticle and epicuticle via the tubules. The mechanism of aerosol formation was reported for $\mathrm{H}$. lamae (Yin et al., 1991) in which the droplets are sheared from the microtrichia (spines) that located near the orifices of each gland during the pulsation of the abdominal segments. Conner et al., (1980) concluded that the spines lining the pheromone gland of Utethesia ornatrix increased the gland' surface area, as well as preventing collapse of the gland as it ventilated pheromone to the gland's orifice. These histological studies support that the gland in female $S$. littoralis is found in the abdominal cavity and the ventral integument of the $9^{\text {th }}$ are the sources of the female sex pheromone. Strong indications for this including that the cells exhibit typical characteristics of glandular epithelium such as cellular membrane in folding along the whole line between cell and cuticle. The cytoplasm has a fibrous appearance because it is always observed in the cells with deep basal folds of the cellular membrane. The cuticle covering the glandular epithelium in Spodoptera littoralis is thick and soft possibly facilitating pheromone penetration by these special qualities, the glandular cells directly attach to the endocuticle, which also may represent a site for pheromone accumulation. Thus the cuticle might play an important role in the regulation of pheromone emission. The presence of striated border which play an important role in the secretion.

\section{REFERENCES}

Aubery, J. G., Boudreaux, H.B., Grodner, M. L. and Hammond, A. M. (1983). Sex pheromone- producing cells and their associated cuticle in female Heliothis zea and $H$. virescens (Lepidoptera: Noctuidae). Annals of the Entomological Society of America, 76: 343-348.

Conner, W. E.; Eisner, T.; Vander Meer, T. K.; Guerrero, A.; Ghiringelli, D. and Meinwald, J. (1980). Sex attractant of an arctiid moth Utethesia ornatrix: a pulsed chemical signal. Behav. Biol. Sociobiol. 7: 55-63.

Drury, R. A. and Wallington, E. A. (1967). Carleton's Histological technique. $4^{\text {th }}$ edition. New York.

Kou, R.; Chow, Y. S.; Takahashi, S and Yamaoka, R. (1991): Evidence for presence and nature of female sex pheromone of Brithys crini Fabricius. (Lepidoptera: Noctuidae). Journal of Chemical Ecology vol. 17, No 10. 
Ma, P. W. and Roelofos, W. L. (2002). Sex pheromone gland of the female European corn borer moth, Ostrinia nubilalis (Lepidoptera: Pyralidae): ultrastructural and biochemical evidences. Zoolog Sci., 19(5): 501-11.

Miller, T.; Jefferson, R. N., and Thomson, W.W. 1967. Sex pheromones of Noctuid moths. XI. The ultrastructure of apical region of cells of the female sex pheromone gland of Trichoplusia ni. Ann. Entomol. Soc. Am., 60: 707-708.

Percy-Cunningham, J. E. and MacDonald, J.A. (1987). Biology and ultrastructure of sex pheromone-producing glands. In: Prestwich, G. D., Blomquist, G. J. (Eds.). Pheromone Biochemistry. Academic Press, Orlando, FL, pp. 27-75.

Precy, J. E., and Weatherston, J. (1971): Studies of physiologically active arthropods secretions.X.Morphology and histology of the pheromone producing glands of some female Lepidoptera. Canadian Entomol, 103:1733-1739.

Raina, A. K., Wergin, W. P., Murphy, C. A. and Erbe, E. F. (2000). Structural organization of the sex pheromone gland in Helicoverpa zea in relation to pheromone production and release. Arthropod Structural \& Development, 29: 343-353.

Raspotnig, G.; Schicho, R.; Stabentheiner, E.; Magnes, C. and Stelzl, M. (2003). Morphology of female sex pheromone gland in the horse chestnut leaf miner Cameraria ohridella ( Lepidoptera: Gracillariidae). J. Appl. Ent., 127: 121-126.

Rojas, J. C., Carrasco, J. V. and Tovar, J. C. (1995). Morphological Evidence for possible sites of production of the female sex pheromone of Copitarsia consueta (Lepidoptera: Noctuidae). Florida Entomologist, 78(2): 360-363.

Steinbrect, R.A. (1982). Electrophysiological assay of synthetic and natural sex pheromones in the African armyworm moth, Spodoptera exempta. Entomologia Experimentalis Et Applicata, 32 (1):13-22.

Suwanjarat, J. and Witethom, B. (1995). Histology of the female sex pheromone gland of the Sapodilla fruit borer (Lepidoptera: Pyralidae). Science Asia, 21:117-123.

Yin, L.S.S.; Schal, C. and Carde, R.T. (1991). Sex pheromone gland of the female tiger moth Holomelina lamae (Lepidoptera: Arctiidae). Can. J. Zool., 69: 1916-1921. 

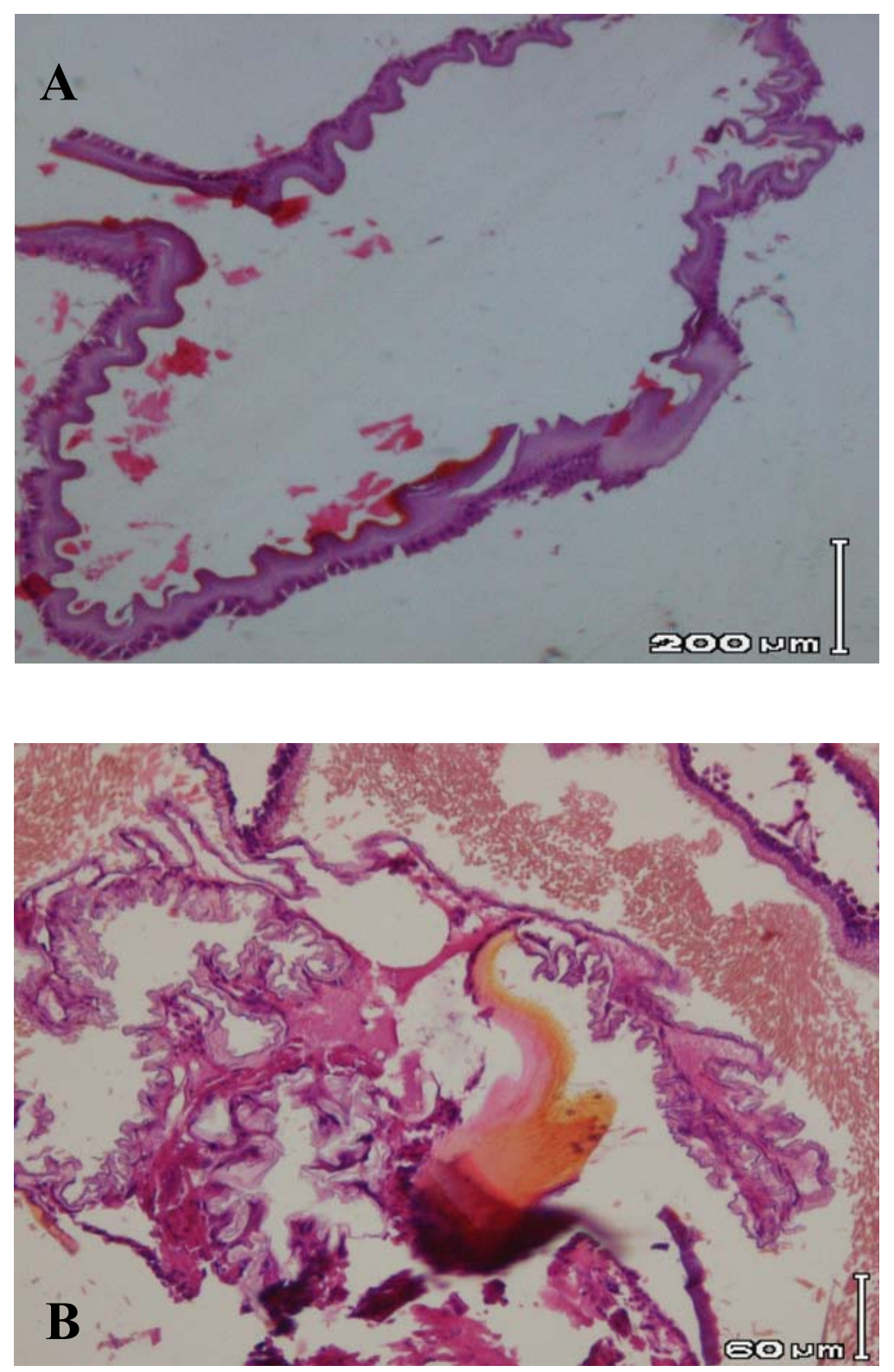

Plate 1: Photomicrograph of abdominal tips showing:

A- The gland lies in the body cavity. H\&E Stain

B- Extensive convolutions of the ventral surface were evident in the $9^{\text {th }}$ segments. H\&E Stain 

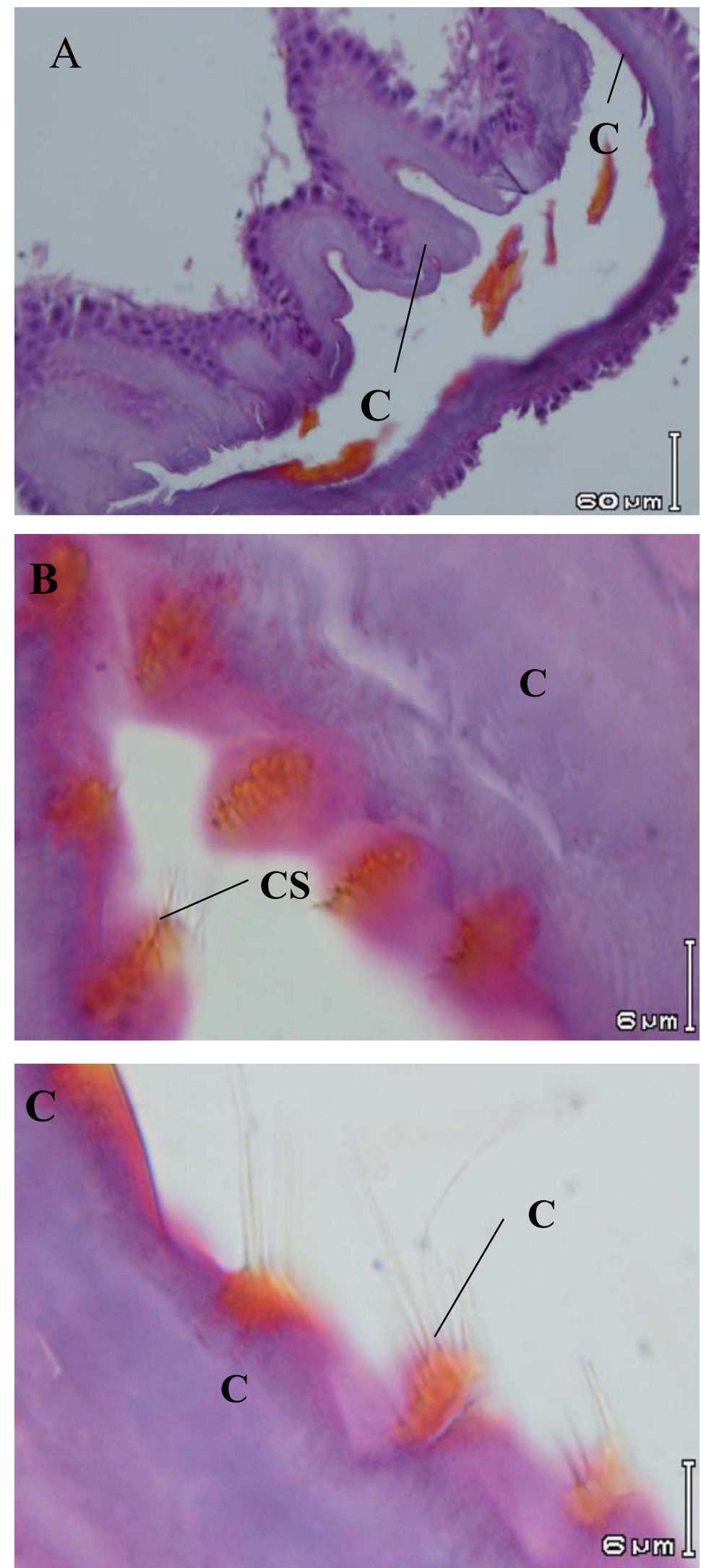

Plate 2: Histological sections in the gland showing:

A- The eversible sac lined with cuticular layer (C) with distinct spines (CS) pointed toward the lumen of the sac. H\&E Stain

B \&C-Magnification of the eversible sac showing the cuticle (C) and the cuticular spines (CS). H\&E Stain. 

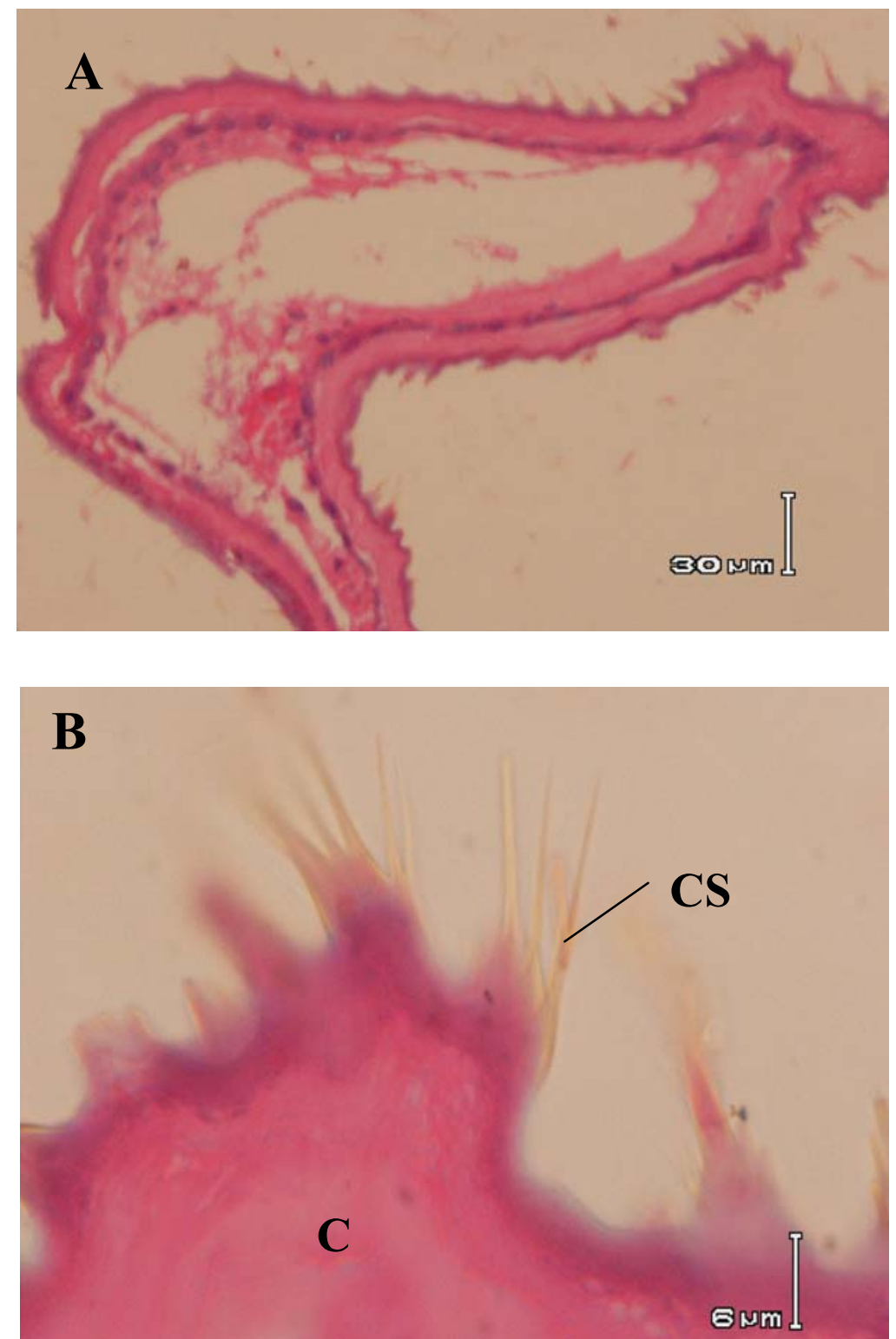

Plate 3: Photomicrograph of the gland showing:

A- The sac is everted out for releasing the secretion. H\&E Stain

B- Magnification of the everted sac showing the cuticle (C) and the cuticular spines (CS). H\&E Stain 

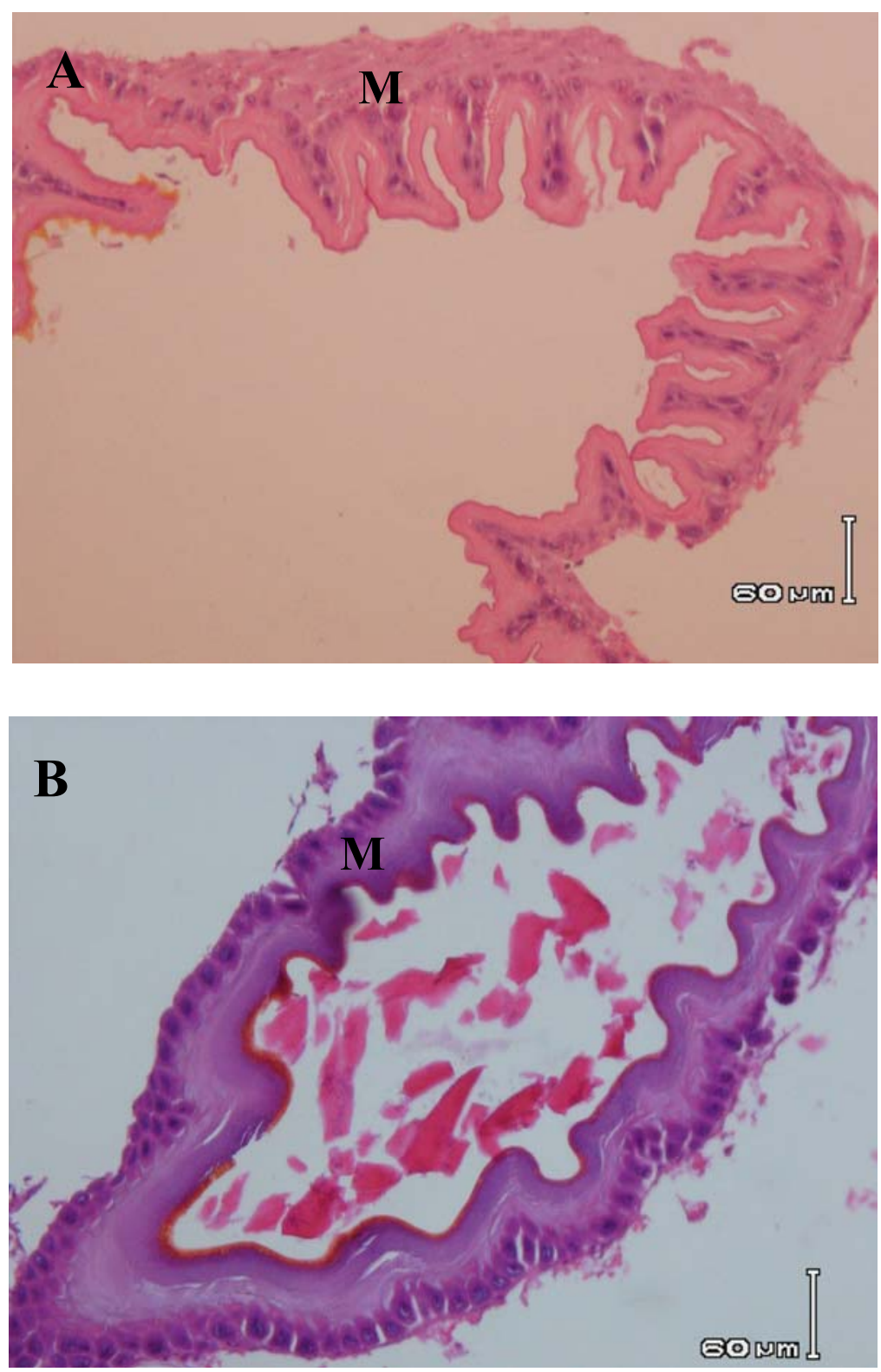

Plate 4: Photomicrograph of the gland showing:

A- The anterior secretory portion of the gland which surrounded by muscles (M). H\&E Stain

B- The posterior storage portion of the gland that lack of muscle. H\&E Stain 

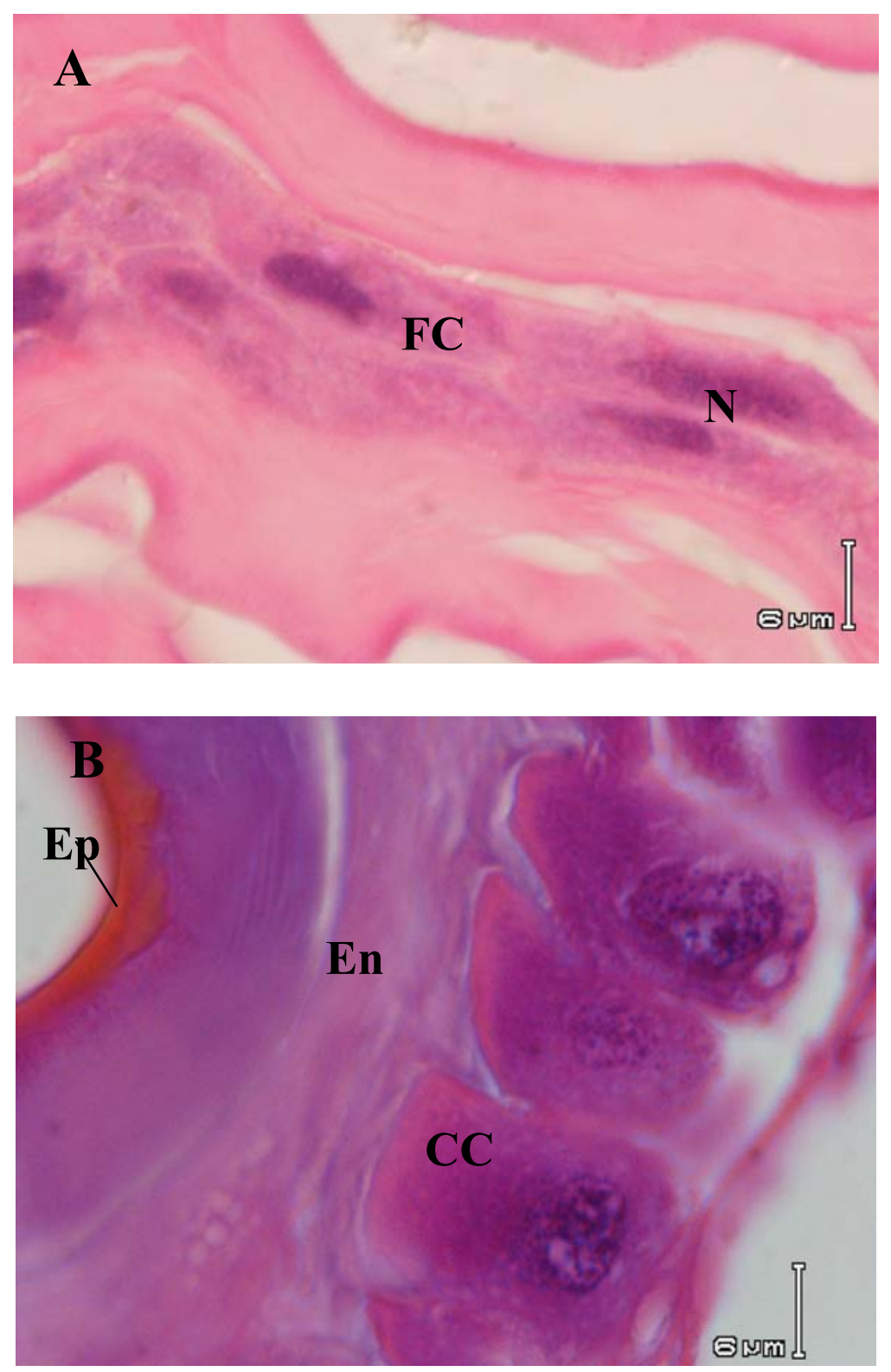

Plate 5: Photomicrograph of the gland showing:

A- Magnification of the secretory portion showing; flattened cells (FC) with compressed nuclei $(\mathrm{N})$ found in the folds. Stain H\&E

B- Magnification of the storage portion showing the columnar cells (CC) with large circular or oval nuclei $(\mathrm{N})$ which may centric or basal in position, epicuticle ( Ep), endocuticle (En). Stain H\& 

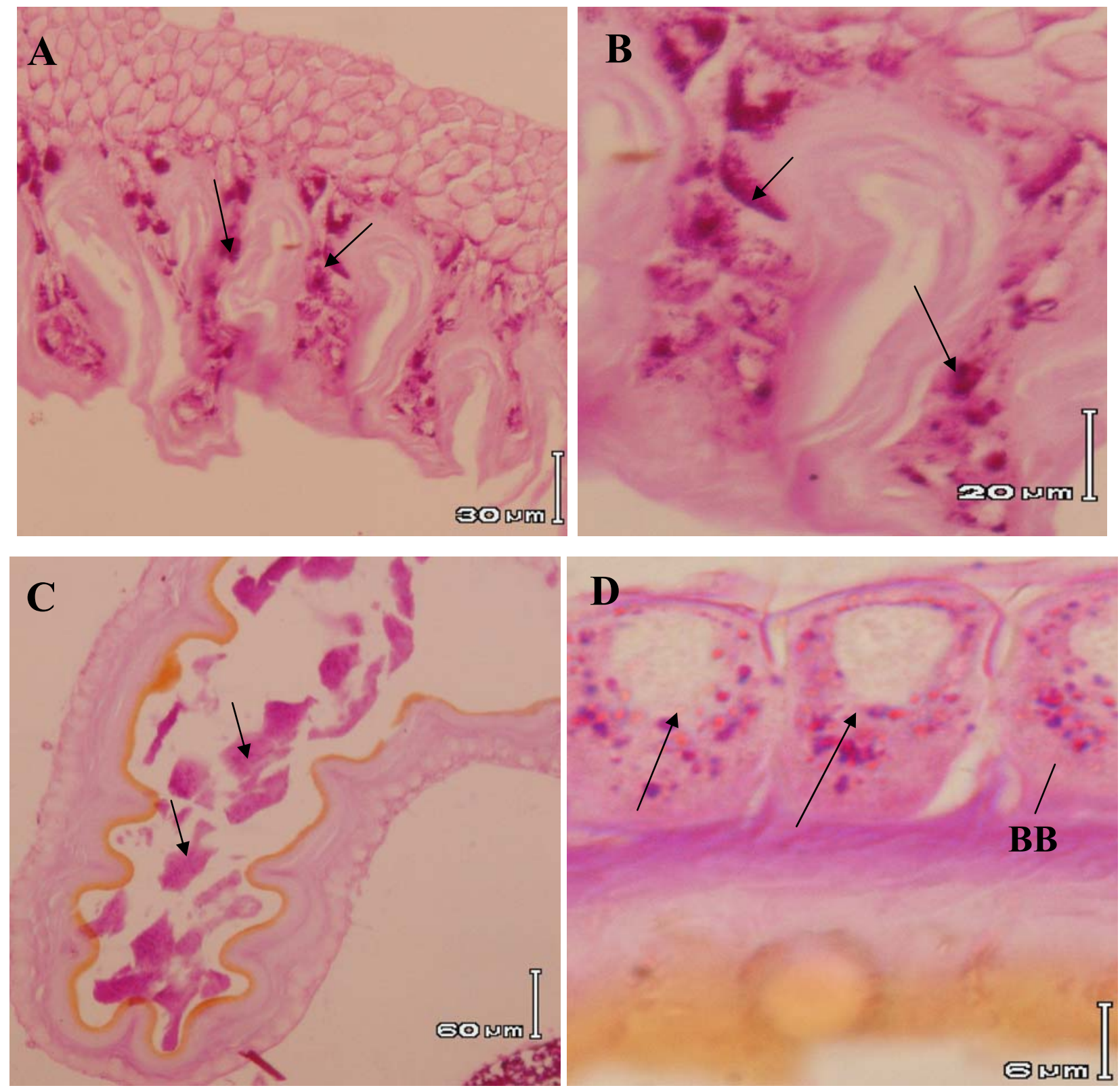

Plate 6: Photomicrograph of the gland showing:

A\&B- Magnification of the secretory portion showing intensely PAS-positive substances were demonstrated intracellular (arrows). PAS stain

C\&D- Magnification of the storage portion showing PAS-positive granules were demonstrated intracellular, the leuminal contents are intensely PAS stained (arrows), brush border (BB). PAS stain. 

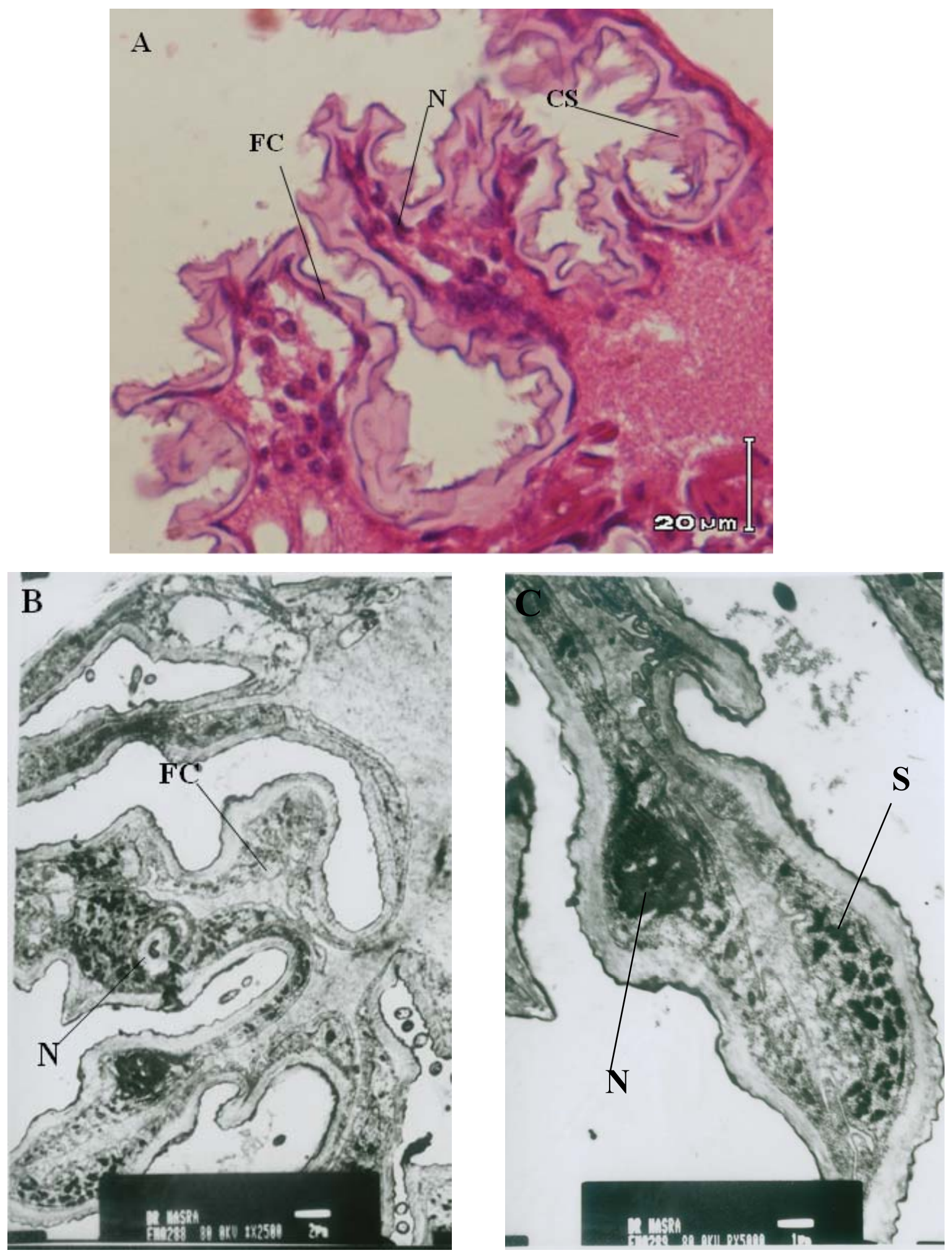

Plate 7:

A- Cross sections of abdominal tips showing the epithelial cells in the ventral surface of ninth segment are flattened (FC) contained large nuclei (N) and the cuticle lined with spines (CS). Stain H\&E

B- Transmission electron microscopy of the ventral surface of the $9^{\text {th }}$ segment showing the cells are flattened (FC), large nuclei $(\mathrm{N})$ and the presence of electron opaque spherical bodies (SB). 


\section{ARABIC SUMMERY}

دراسات هيستولوجية للمناطق المسئولة عن انتاج الفرومونات الخاصة بالاتثى فى فراشة ورق القطن التون الكبرى

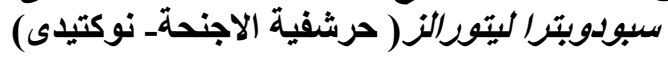

$$
\text { قسم علم الحيو ان ـ كلية العلوم- جامعن زهر سو هاج }
$$

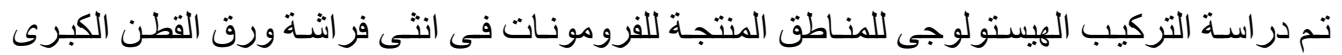

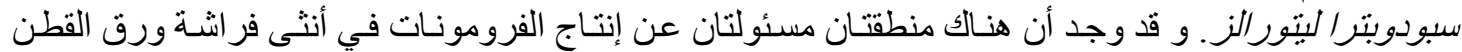

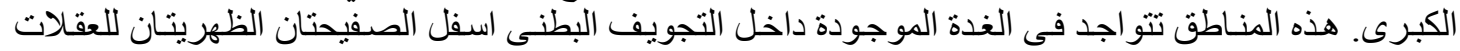

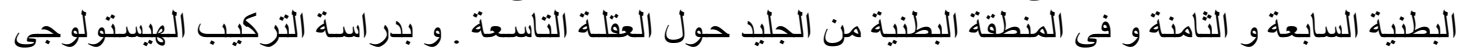

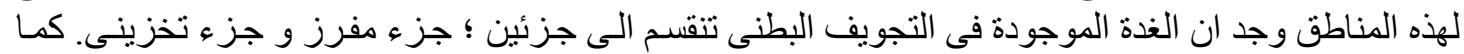

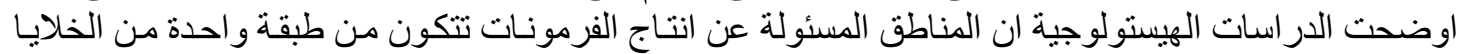

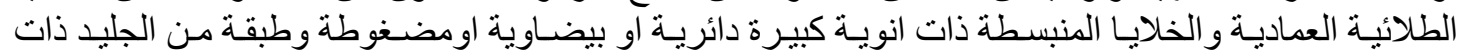

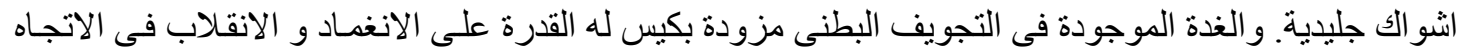

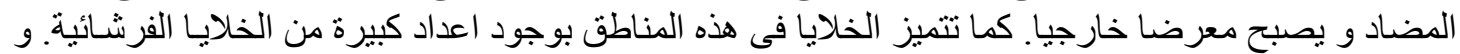

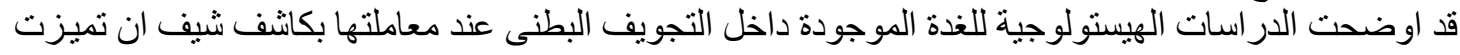
خلايا الجزء المفرز بالصبغة الداكنة اما فى الجزء التخزينى ترسبت حبييات داخل الخلايا مع ظهور صبغة دالئة داكنة فى تجويف الغدة. 